\title{
External Apical Root Resorption and IL-1A, IL-1RN Gene Polymorphisms: A Systematic Review and Meta-Analysis of Prospective Studies
}

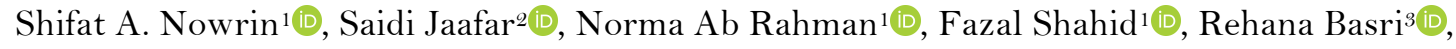 \\ Mohammad Khursheed Alam ${ }^{4}$ (I)
}

${ }^{1}$ Orthodontic Unit, School of Dental Sciences, Universiti Sains Malaysia, Kubang Kerian, Kelantan, Malaysia.

${ }^{2}$ Craniofacial Biology Research Group, School of Dental Sciences, Universiti Sains Malaysia, Kubang Kerian, Kelantan, Malaysia.

${ }^{3}$ Department of Medicine, College of Medicine, Jouf University, Sakaka, Kingdom of Saudi Arabia.

${ }^{4}$ Orthodontic Unit, College of Dentistry, Jouf University, Sakaka, Kingdom of Saudi Arabia.

Correspondence: Dr. Saidi Jaafar, School of Dental Sciences, Universiti Sains Malaysia, Kubang Kerian 16150, Kelantan, Malaysia. E-mail: saidijaafar@usm.my

Academic Editor: Catarina Ribeiro Barros de Alencar

Received: 06 October 2020 / Review: 16 November 2020 / Accepted: 26 November 2020

\begin{abstract}
How to cite: Nowrin SA, Jaafar S, Rahman NA, Shahid F, Basri R, Alam MK. External apical root resorption and IL-1A, IL-1RN gene polymorphisms: a systematic review and meta-analysis of prospective studies. Pesqui Bras Odontopediatria Clín Integr. 202 1; 21:e0217. https://doi.org/10.1590/pboci.2021.065
\end{abstract}

\begin{abstract}
Objective: To reconnoiter the IL-1A (-889) and IL-1RN (+2018) gene polymorphisms and their association with EARR. Material and Methods: The Science Direct, PubMed and Scopus databases were comprehensively searched by two independent reviewers. In addition, the bibliographies of all relevant publications and textbooks were searched manually. A meta-analysis was performed using data available up to May 9, 2020. Results: A total of 13 and 9 publications were selected for the systematic review and metaanalysis, respectively for both IL-1A and IL-1RN genes. Odds ratio (OR) was used to evaluate the association of the gene polymorphism and the risk of EARR. The risk of EARR was estimated using the overall OR from the published studies. No association was found for IL-1A gene for the risk of EARR. However, the dominant and co-dominant models of IL-1RN gene polymorphism were associated with the risk of EARR. Conclusion: More studies are warranted to determine the relationship between IL-1A and IL-1RN gene polymorphisms and EARR for a clearer understanding of their interactions.
\end{abstract}

Keywords: Polymorphism, Genetic; Root Resorption; Orthodontics; Study Characteristics. 


\section{Introduction}

External apical root resorption (EARR) is a shortening of the root apex, which can be acquired due to various mechanical and/or genetic factors [1]. Orthodontic treatment is known to be one of the triggering factors in developing EARR in most cases, although the exact etiology is still debated. Several studies have been conducted to determine the genetic association and the orthodontic-induced EARR in various populations [1-4]. Most of the studies focused on different polymorphisms in interleukins (ILs), Vitamin D receptor (VDR), Tumour Necrosis Factor-alpha (TNF- $\alpha)$, and Cluster of Differentiation (CD) genes to establish their association with EARR in certain populations [5].

Interleukin-1 (IL-1) is encoded by interleukin-1A gene and interleukin-1B gene located at chromosomal band 2q14 in a cluster that also contains the genes for the IL-1 receptors type 1 and 2 (IL-1R 1 and IL-1R2), the IL-1 receptor antagonist (IL-1RN) and six other homologues, the interleukin-1 family members 5-10 [6]. However, previously reported investigations were mainly focused on the association of IL1A, IL-1B and/or IL-1RN genes with EARR during orthodontic treatments [7-9]. Initially, Al-Qawasmi et al. [1] showed the association between single nucleotide polymorphisms (SNPs) of IL-1A (-889) and IL-1B (+3954) gene polymorphisms and the EARR among the Caucasians in America. Then, similar SNPs association have also been shown in some other European [3,7,9,10] and Asian [4] populations. Unfortunately, the outcomes were inconsistent and contradictory.

A few systematic reviews exist to address the divergent results of the genetic association studies with EARR and mainly focused on IL-1B gene only [11,12]. However, no systematic review is available on IL-1A and IL-1RN genes association with EARR in orthodontic treatment. Therefore, the aim of this systematic review and meta-analysis was to determine whether these two important genes in IL-1 cluster, IL-1A and IL$1 \mathrm{RN}$ genes are associated with EARR during orthodontic treatment.

\section{Material and Methods}

This systematic review complied to the PRISMA guidelines. PICOS format was followed in terms of the participants, interventions, comparisons, outcomes, and study designs for a better outline of the review [11]. Three main search engines, namely PubMed, Scopus database and Science Direct, were searched (publications included until 9th May 2020) using the keywords "EARR, external apical root resorption, genetic polymorphism, orthodontic treatment, Interleukin-1, IL-1A and IL-1RN" without any restrictions on language, treatment duration, population and sample size of the studies. All appropriate publications were selected and references of the particular publications were cross-checked for any unnoticed related studies throughout the electronic searches.

The inclusion criteria for these previously published studies were firstly, the association between genetic polymorphisms and the risk of EARR and secondly, genotypes determined by calculating the odds ratios (ORs). On the other hand, publications with duplication of data, review articles, and publications with insufficient data were excluded from this review. All the published studies on IL-1A and IL-1RN genes were independently scrutinized after the literature search by two reviewers and then selected according to the inclusion and exclusion criteria set for this review. No disagreement was recorded between the two reviewers and the publications for both genes were selected for the systematic review after fulfilled the criteria.

The strengthening the reporting of genetic association (STREGA) statement and checklist were followed in ensuring the quality of evaluation. Twelve methodologic quality scores have been calculated and ranged from o (lowest) to 20 (highest). Publications with scores $<10$ were considered as low-quality studies 
and publications with scores $\geq 10$ were considered as high-quality studies. Meta-analyses were then performed based on the association of IL-1A (-889) and IL-1RN (+2018) gene polymorphisms with the EARR consequences of selected publications.

\section{Statistical Analysis}

IBM SPSS Statistics for Windows version 24.0 (IBM Co., Armonk, NY, USA) and Comprehensive Meta-Analysis (CMA) Software version 3 (Biostat, Englewood, NJ, USA) were utilized for the statistical analyses. Cohen's kappa analysis was performed to identify the interobserver agreement of the grading qualities of the publications. The level of agreement was graded according to the kappa scores, with 0.81-1, 0.61-0.80, 0.41-0.60, 0.21-0.40, and < 0.20, which indicating near perfect, substantial, moderate, fair, and poor agreement, respectively [13]. The power of the association between EARR and gene polymorphisms was estimated with the ORs with corresponding 95\% confidence intervals (CI). The pooled OR from the selected publications were obtained from the dominant model (CC + CT vs. TT), co-dominant model (CC vs. TT or CT vs. TT), and recessive model (CC vs. CT + TT). Residuals were checked for each study for suspected outliers. $Q$ statistics and $\mathrm{I}^{2}$ statistics were performed for the heterogeneity test. $\mathrm{I}^{2}<50 \%$ and a p-value of $\mathrm{Q}$ statistics $>$ 0.10 indicated a lack of heterogeneity across the studies. Moreover, a funnel plot was used to determine publication bias, where an asymmetric plot specified possible bias. The funnel plot was assessed with the Begg's test [14] and Egger's test [15]. The presence of bias among the studies was indicated if a p-value was $<0.05$, whereas a p-value $>0.05$ was considered to indicate the opposite. Similar statistics were performed for both IL$1 \mathrm{~A}$ and IL-1RN genes.

\section{Results}

The selection of publications for IL-1A and IL-1RN genes were strictly followed the PRISMA guidelines (Figure 1 and Figure 2). The total number of publications identified for IL-1A gene was 9 (5 from PubMed, 2 from Scopus and 2 from Science Direct) and for IL-1RN gene was 10 (5 from PubMed, 2 from Scopus and 4 from Science Direct), after being confirmed by the two independent reviewers. Subsequently, discarding duplicates, 7 publications were selected for the IL-1A gene [1-3,7,16-18] and 6 publications were chosen for IL-1RN gene $[2,3,8,10,18,19]$ to be included in this systematic review (Table 1). A total of 6 publications for IL-1A (-889) gene polymorphism [2,3,7,16-18] and 3 publications for the IL-1RN (+2018) gene polymorphism $[2,8,18]$ were considered for meta-analysis (Table 2 ).

STREGA guideline was followed to assess the quality of all selected publications for this systematic review [14,15], which was performed by two independent reviewers. From 13 publications initially chosen for the systematic review for both IL-1A and IL-1RN genes, only 9 publications were selected for quality assessment due to overlapping of the gene studied. Among the 9 selected publications, 5 were classified as high-quality studies $(\geq 10)$ and 4 as low-quality studies $(<10)$ (Table 3$)$. Inter-rater reliability for these five criteria was 0.857 , which represented a near perfect level of agreement. Cohen's kappa score for most of the criteria showed an absolute level of inter-rater agreement (Table 4).

The analysis of the association of EARR risk with the IL-1RN (+2018) polymorphism showed that its dominant model and co-dominant models were associated with the risk of EARR while its recessive model was not associated with the risk of EARR. Meanwhile, the IL-1A (-889) gene polymorphism showed that none of the dominant, co-dominant, and recessive models were associated with the risk of EARR. Although a lessexpected frequency residual was detected because of a sampling error, it nevertheless could still be counted in 
the meta-analysis in the random-effect model without significantly influencing the outcome [11] (Figure 3, Figure 4 and Table 5).

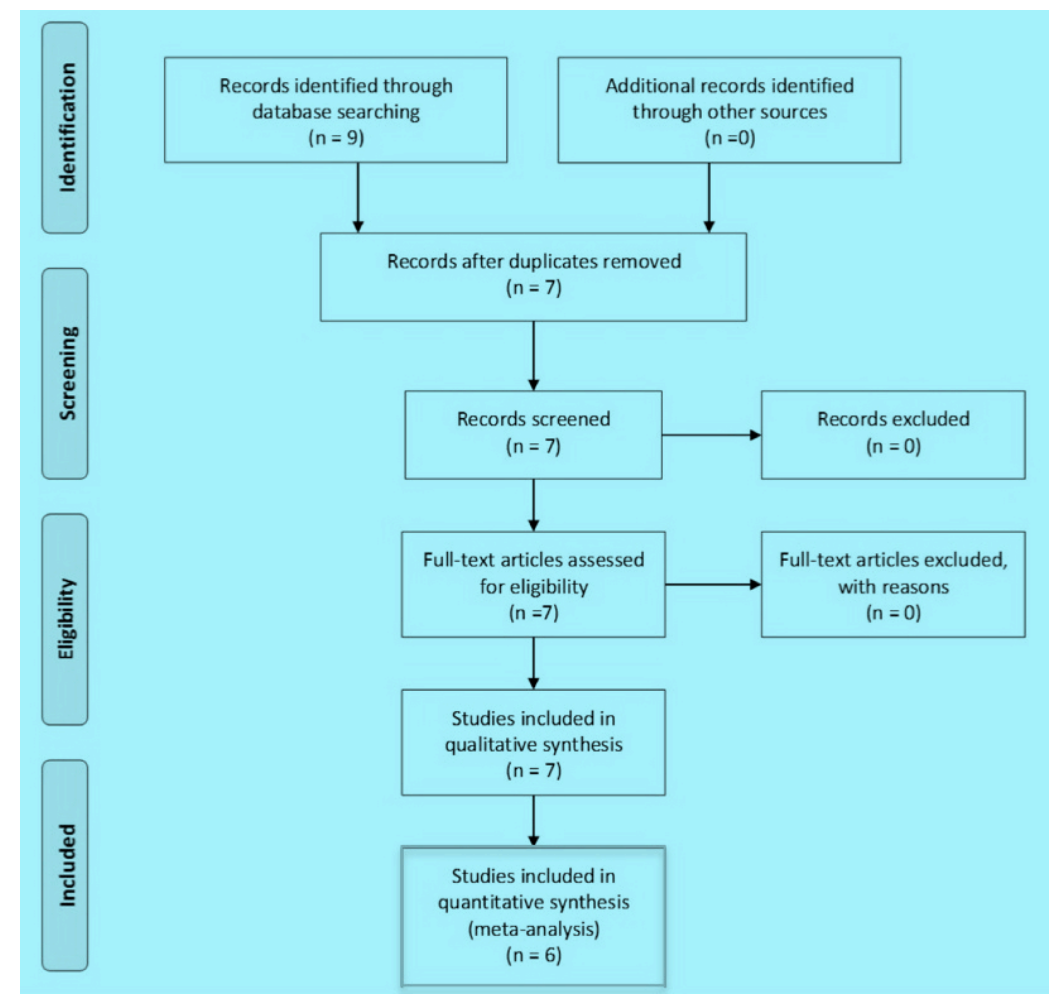

Figure 1. Flow chart of the PRISMA guidelines for IL-1A gene study selection.

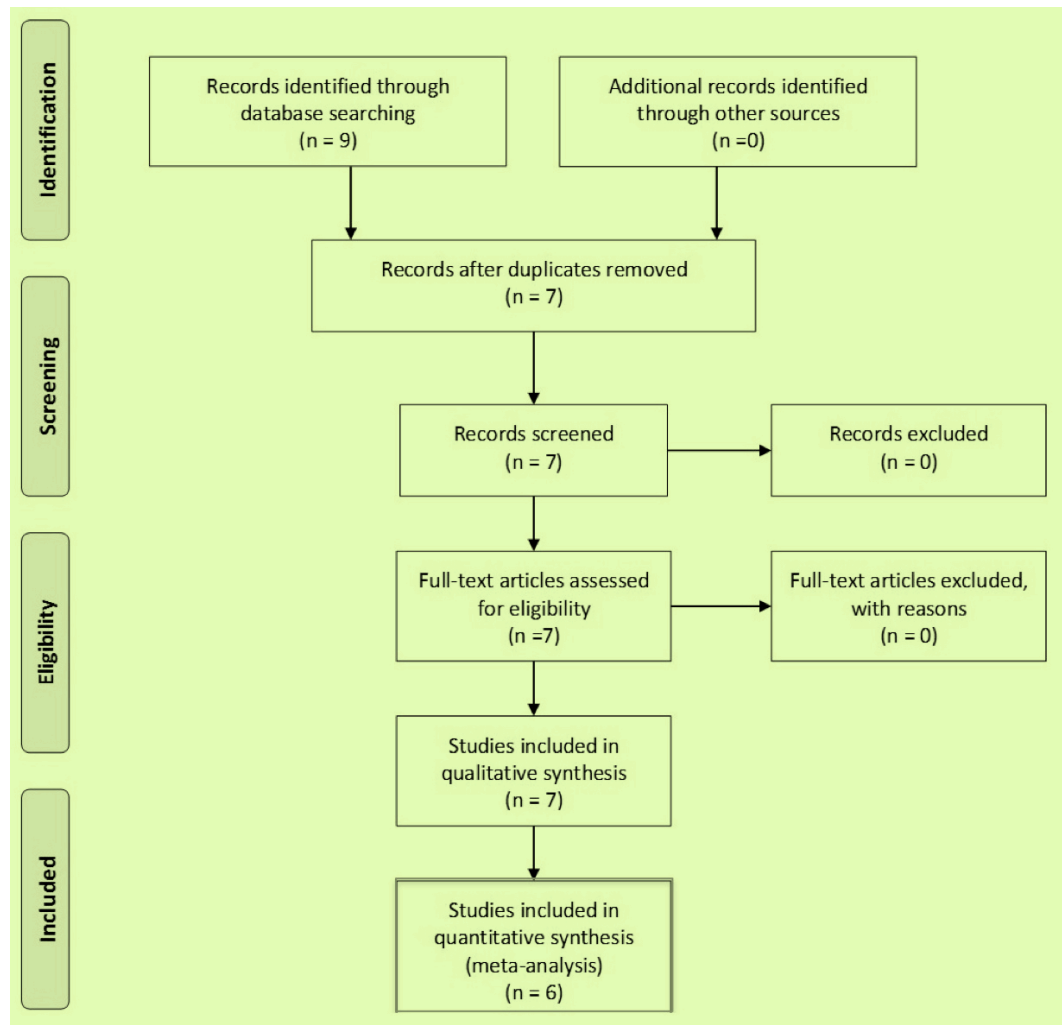

Figure 2. Flow chart of the PRISMA guidelines for IL-1RN gene study selection. 
Table 1. Main characteristic of included studies for IL-1A and IL-1RN genes.

\begin{tabular}{|c|c|c|c|c|c|c|c|c|}
\hline Gene & Author & Country & Ethnicity & Sample Size & Radiographs Used & $\begin{array}{l}\text { Genotype } \\
\text { Method }\end{array}$ & $\begin{array}{l}\text { Biological } \\
\text { Marker }\end{array}$ & Outcome \\
\hline \multirow[t]{7}{*}{ IL-1A } & $\begin{array}{c}\text { Al-Qawasmi et al. } \\
{[1]}\end{array}$ & USA & Caucasian & $\begin{array}{l}118 \text { subjects } \\
\text { from } 35 \\
\text { families }\end{array}$ & $\begin{array}{c}\text { Lateral Cephalogram } \\
\text { and OPG }\end{array}$ & Ncoi and TaqI & $\begin{array}{l}\text { IL- } 1 \mathrm{~A} \text { and IL- } \\
1 \mathrm{~B}\end{array}$ & $\begin{array}{l}\text { IL-1B gene, known to decrease the } \\
\text { production of IL-1 cytokine in vivo, } \\
\text { significantly increases the risk of EARR. }\end{array}$ \\
\hline & $\begin{array}{l}\text { Iglesias-Linares } \\
\text { et al. [2] }\end{array}$ & Spain & White & 54 & $\begin{array}{c}\text { Lateral Cephalogram } \\
\text { and OPG }\end{array}$ & $\begin{array}{l}\text { HotStar Taq } \\
\text { polymerase }\end{array}$ & $\begin{array}{l}\text { IL-1A, IL-1B } \\
\text { and IL-1RN }\end{array}$ & $\begin{array}{l}\text { Not only in the IL-1B gene are determinants } \\
\text { of a predisposition to postorthodontic } \\
\text { EARR. }\end{array}$ \\
\hline & $\begin{array}{c}\text { Linhartova et al. } \\
{[3]}\end{array}$ & $\begin{array}{c}\text { Czech } \\
\text { Republic }\end{array}$ & $\begin{array}{c}\text { Not } \\
\text { Mentioned }\end{array}$ & 106 & $\begin{array}{c}\text { Lateral Cephalogram } \\
\text { and OPG }\end{array}$ & $\begin{array}{l}\text { Ncoi, TaqI and } \\
\text { VNTR-PCR }\end{array}$ & $\begin{array}{l}\text { IL-1A, IL-1B } \\
\text { and IL-1RN }\end{array}$ & $\begin{array}{l}\text { No significant role of IL-1A and IL-1B } \\
\text { variants in EARR was confirmed, IL-1RN } \\
\text { VNTR may be associated with EARR, } \\
\text { especially in girls. }\end{array}$ \\
\hline & Gülden et al. [7] & German & $\begin{array}{c}\text { Not } \\
\text { Mentioned }\end{array}$ & 258 & OPG & Ncoi and TaqI & $\begin{array}{l}\text { IL1A and IL- } \\
1 \mathrm{~B}\end{array}$ & $\begin{array}{l}\text { IL-1A polymorphism point to an association } \\
\text { of the genotype } 2-2 \text { with EARR and IL-1B } \\
\text { polymorphism in patients revealed no } \\
\text { indication of a predisposition of EARR. }\end{array}$ \\
\hline & $\begin{array}{l}\text { Iglesias-Linares } \\
\text { et al. }[16]\end{array}$ & Spain & White & 73 & $\begin{array}{l}\text { Lateral Cephalogram } \\
\text { and OPG }\end{array}$ & $\begin{array}{l}\text { HotStar Taq } \\
\text { polymerase }\end{array}$ & $\begin{array}{l}\text { IL- } 1 \mathrm{~A} \text { and IL- } \\
1 \mathrm{~B}\end{array}$ & $\begin{array}{l}\text { The development of EARR in subjects with } \\
\text { root-filled teeth who undergo orthodontic } \\
\text { treatment might be attributable to genetic } \\
\text { variations in the interleukin-1B gene }\end{array}$ \\
\hline & $\begin{array}{l}\text { Iglesias-Linares } \\
\text { et al. }[17]\end{array}$ & Spain & $\begin{array}{c}\text { Not } \\
\text { Mentioned }\end{array}$ & 146 & $\begin{array}{c}\text { Lateral Cephalogram } \\
\text { and OPG }\end{array}$ & $\begin{array}{l}\text { HotStar Taq } \\
\text { polymerase }\end{array}$ & $\begin{array}{l}\text { IL- } 1 \mathrm{~A} \text { and IL- } \\
1 \mathrm{~B}\end{array}$ & $\begin{array}{l}\text { Genetic inheritance of IL-1B gene, in } \\
\text { homozygous subjects is associated with a } \\
\text { two times increased predisposition to have } \\
\text { EARR secondary to orthodontic tooth } \\
\text { movement in endodontically treated teeth. }\end{array}$ \\
\hline & Sharab et al. [18] & USA & Caucasian & 460 & $\begin{array}{l}\text { Lateral Cephalogram, } \\
\text { OPG and occlusal }\end{array}$ & Not mentioned & $\begin{array}{l}\mathrm{P} 2 \mathrm{RX}_{7} \\
\mathrm{CASP} 1, \mathrm{IL}- \\
1 \mathrm{~B}, \mathrm{IL}-1 \mathrm{~A} \text { and } \\
\quad \mathrm{IL}-1 \mathrm{RN}\end{array}$ & $\begin{array}{l}\text { EARR occurrence was associated with both } \\
\text { genetic and treatment-related variables, } \\
\text { which together explained } 25 \% \text { of the total } \\
\text { variation associated with EARR in the } \\
\text { sample tested. }\end{array}$ \\
\hline \multirow[t]{2}{*}{ IL-1RN } & $\begin{array}{c}\text { Linhartova et al. } \\
{[3]}\end{array}$ & $\begin{array}{c}\text { Czech } \\
\text { Republic }\end{array}$ & $\begin{array}{c}\text { Not } \\
\text { Mentioned }\end{array}$ & 106 & $\begin{array}{c}\text { Lateral Cephalogram } \\
\text { and OPG }\end{array}$ & $\begin{array}{l}\text { Ncoi, TaqI and } \\
\text { VNTR-PCR }\end{array}$ & $\begin{array}{l}\text { IL-1A, IL-1B } \\
\text { and IL-1RN }\end{array}$ & $\begin{array}{l}\text { No significant role of IL-1A and IL-1B } \\
\text { variants in EARR was confirmed, IL-1RN } \\
\text { VNTR may be associated with EARR, } \\
\text { especially in girls. }\end{array}$ \\
\hline & Iglesias-Linares & Spain & Caucasian & 93 & Lateral Cephalogram & HotStar Taq & IL-1RN & IL-1RN gene associated with an increased \\
\hline
\end{tabular}




\begin{tabular}{|c|c|c|c|c|c|c|c|}
\hline et al. [8] & & & & and $\mathrm{OPG}$ & polymerase & & $\begin{array}{l}\text { risk of suffering post- orthodontic EARR in } \\
\text { root-filled teeth. }\end{array}$ \\
\hline Pereira et al. $[10]$ & Portugal & $\begin{array}{l}\text { Portuguese } \\
\text { Caucasian }\end{array}$ & 195 & OPG & $\begin{array}{l}\text { TaqI and Taq- } \\
\text { man }\end{array}$ & $\begin{array}{l}\text { IL-1B, IL- } \\
1 \mathrm{RN} \text { and } \\
\text { IRAK } 1\end{array}$ & $\begin{array}{l}\text { IRAK } 1 \text { polymorphism is proposed as a } \\
\text { protective variant for EARR. }\end{array}$ \\
\hline $\begin{array}{l}\text { Iglesias-Linares } \\
\quad \text { et al. }[16]\end{array}$ & Spain & White & 54 & $\begin{array}{l}\text { Lateral Cephalogram } \\
\text { and OPG }\end{array}$ & $\begin{array}{l}\text { HotStar Taq } \\
\text { polymerase }\end{array}$ & $\begin{array}{l}\text { IL-1A, IL-1B } \\
\text { and IL-1RN }\end{array}$ & $\begin{array}{l}\text { Not only in the IL-1B gene are determinants } \\
\text { of a predisposition to postorthodontic } \\
\text { EARR. }\end{array}$ \\
\hline Sharab et al. [18] & USA & Caucasian & 460 & $\begin{array}{l}\text { Lateral Cephalogram, } \\
\text { OPG and occlusal }\end{array}$ & Not mentioned & $\begin{array}{l}\mathrm{P} 2 \mathrm{RX} 7 \\
\text { CASP1, IL- } \\
\text { 1B, IL-1A and } \\
\quad \text { IL-1RN }\end{array}$ & $\begin{array}{l}\text { EARR occurrence was associated with both } \\
\text { genetic and treatment-related variables, } \\
\text { which together explained } 25 \% \text { of the total } \\
\text { variation associated with EARR in the } \\
\text { sample tested. }\end{array}$ \\
\hline Guo et al. [19] & China & Chinese & 174 & $\mathrm{CBCT}$ & Taq-man & $\begin{array}{l}\text { IL-6 and IL- } \\
\text { RN }\end{array}$ & IL-6 SNP GC is a risk factor for EARR. \\
\hline
\end{tabular}

Table 2. Characteristics of included studies of IL-1A and IL-1RN gene for meta-analysis.

\begin{tabular}{|c|c|c|c|c|c|c|c|c|c|}
\hline \multirow{3}{*}{ Gene } & \multirow{3}{*}{ Author } & \multirow{3}{*}{ Country } & \multirow{3}{*}{ No of Case/ Control } & \multicolumn{3}{|c|}{ EARR (> 2mm) } & \multicolumn{3}{|c|}{ Control $(<2 \mathrm{~mm})$} \\
\hline & & & & $\mathbf{C C}$ & CT & TT & $\mathrm{CC}$ & CT & TT \\
\hline & & & & $\mathrm{N}(\%)$ & $\mathrm{N}(\%)$ & $\mathrm{N}(\%)$ & $\mathrm{N}(\%)$ & $\mathrm{N}(\%)$ & $\mathrm{N}(\%)$ \\
\hline \multirow[t]{6}{*}{ IL-1A } & Iglesias-Linares et al. [Q2] & Spain & $25 / 29$ & $16(29.6)$ & $8(14.8)$ & $1(1.8)$ & $12(22.2)$ & $13(24.1)$ & $4(7.4)$ \\
\hline & Linhartova et al. [3] & Czech Republic & $32 / 74$ & $37(50.0)$ & $31(41.9)$ & $6(8.1)$ & $16(50.0)$ & $14(43.8)$ & $2(6.2)$ \\
\hline & Gulden et al. [7] & German & $45 / 49$ & $19(42.2)$ & $18(40)$ & $8(17.7)$ & $26(59.1)$ & $17(38.6)$ & $1(2.3)$ \\
\hline & Iglesias-Linares et al. [16] & Spain & $30 / 43$ & $16(21.9)$ & $11(15.06)$ & $3(4.1)$ & $20(27.3)$ & $15(20.54)$ & $8(10.9)$ \\
\hline & Iglesias-Linares et al. [17] & Spain & $39 / 54$ & $24(61.5)$ & $9(23.1)$ & $6(15.4)$ & $24(44.4)$ & $23(42.6)$ & $7(13.0)$ \\
\hline & Sharab et al. [18] & USA & $67 / 67$ & $28(41.8)$ & $28(41.8)$ & $11(16.4)$ & $32(47.8)$ & $29(43.3)$ & $6(9.0)$ \\
\hline \multirow[t]{3}{*}{ IL-1 RN } & Iglesias-Linares et al. [2] & Spain & $25 / 29$ & $2(3.7)$ & $5(9.7)$ & $18(33.3)$ & $4(7.4)$ & $17(31.8)$ & $8(14.8)$ \\
\hline & Iglesias-Linares et al. [8] & Spain & $39 / 54$ & $1(2.6)$ & $6(15.4)$ & $32(82.1)$ & $11(20.4)$ & $27(50.0)$ & $16(29.6)$ \\
\hline & Sharab L et al. $[18]$ & USA & $67 / 67$ & $3(4.5)$ & $23(34.3)$ & $41(61.2)$ & $0(0.0)$ & $29(43.3)$ & $38(56.7)$ \\
\hline
\end{tabular}


Table 3. Quality assessment of included studies.

\begin{tabular}{lcccccc}
\multicolumn{1}{c}{ Author } & Selection & Comparability & Exposure & $\begin{array}{c}\text { Study } \\
\text { Methodologies }\end{array}$ & $\begin{array}{c}\text { Genetic } \\
\text { Analysis }\end{array}$ & Score \\
\hline Al-Al-Qawasmi et al. [1] & $*(1)$ & 0 & 0 & $*(1)$ & $* * * *(5)$ & 7 \\
Iglesias-Linares et al. [2] & $* * * *(4)$ & $*(1)$ & $*(1)$ & $* *(2)$ & $* * * *(5)$ & 13 \\
Linhartova et al. [3] & $* * * *(4)$ & $*(1)$ & $* *(2)$ & $* *(2)$ & $* * * * *(6)$ & 15 \\
Gülden et al. [7] & $* *(2)$ & 0 & 0 & $*(1)$ & $* * * * *(5)$ & 8 \\
Pereira et al. [10] & $*(1)$ & 0 & 0 & $*(1)$ & $* * * * *(6)$ & 8 \\
Iglesias-Linares et al. [16] & $* * * *(4)$ & $*(1)$ & $*(1)$ & $* *(2)$ & $* * * *(5)$ & 13 \\
Iglesias-Linares et al. [17] & $* * * *(4)$ & $*(1)$ & $*(2)$ & $* *(2)$ & $* * * *(4)$ & 13 \\
Sharab et al. [18] & $* * * *(4)$ & $*(1)$ & $* *(2)$ & $*(1)$ & $* * * * *(6)$ & 14 \\
Guo et al. [19] & $* *(2)$ & 0 & $*(1)$ & $* *(2)$ & $* * * *(4)$ & 9 \\
\hline
\end{tabular}

Table 4. Interrater agreement of quality assessment by Cohen's kappa analysis.

\begin{tabular}{ccc}
\hline Quality Assessment & Measure of Agreement Between Raters & Kappa Score \\
\hline Selection & 1 & 0.857 \\
Comparability & 0.769 & \\
Exposure & 1 & \\
Study Methodologies & 1 & \\
Genetic Analysis & 1 & \\
\hline
\end{tabular}

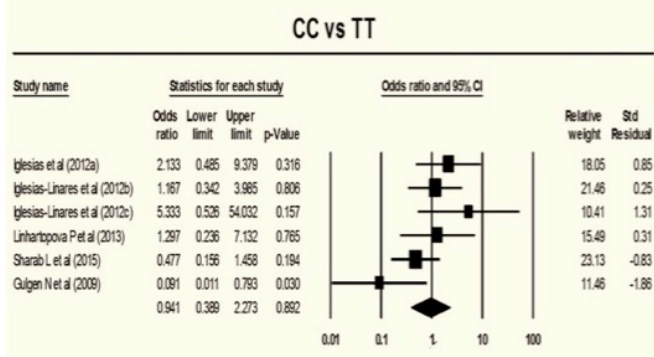

CC vs CT+TT

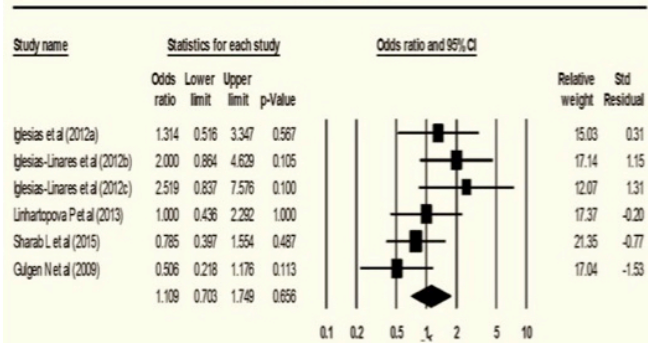

\section{CT vs TT}

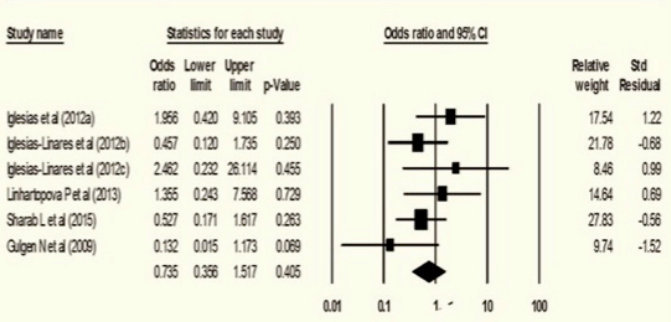

CC+CT vs TT

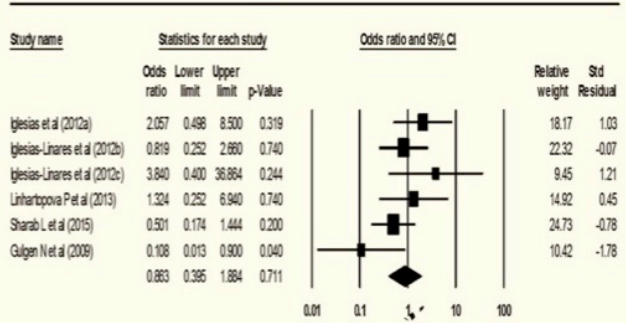

Figure 3. Forest plots of EARR risk associated with the interleukin-1A (-889) gene polymorphism.

Table 5. Risk of EARR with the association of IL-1A (-889) and IL-1RN (+2018) gene polymorphisms.

\begin{tabular}{cccccc}
\hline Gene & Genotypes & Odds Ratio $(\mathbf{O R})$ & \multicolumn{2}{c}{$\mathbf{9 5 \%}$ CI } & p-value \\
& & & Lower & Upper & \\
\hline IL-1A (-889) & CC vs. TT & 0.941 & 0.389 & 2.273 & 0.892 \\
& CT vs. TT & 0.735 & 0.356 & 1.517 & 0.405 \\
& CC + CT vs. TT & 0.863 & 0.395 & 1.884 & 0.711 \\
IL-1RN (+2018) & CC vs. CT + TT & 1.109 & 0.703 & 1.749 & 0.656 \\
& CC vs. TT & 0.117 & 0.033 & 0.422 & $0.001^{*}$ \\
& CT vs. TT & 0.118 & 0.053 & 0.262 & $0.001^{*}$ \\
& CC + CT vs. TT & 0.114 & 0.054 & 0.239 & $0.001^{*}$ \\
& CC vs. CT + TT & 0.535 & 0.137 & 2.091 & 0.368 \\
\hline
\end{tabular}

$\mathrm{CI}=$ Confidence Interval; p-value $<0.05$; \%= Percentage; $\mathrm{C}=$ Cytosine; $\mathrm{T}=$ Thymine; $v s$. = versus; IL-1A = Interleukin-1A; IL-1RN = Interleukin-1RN; EARR = External Apical Root Resorption; *Significant difference $(<0.05)$. 


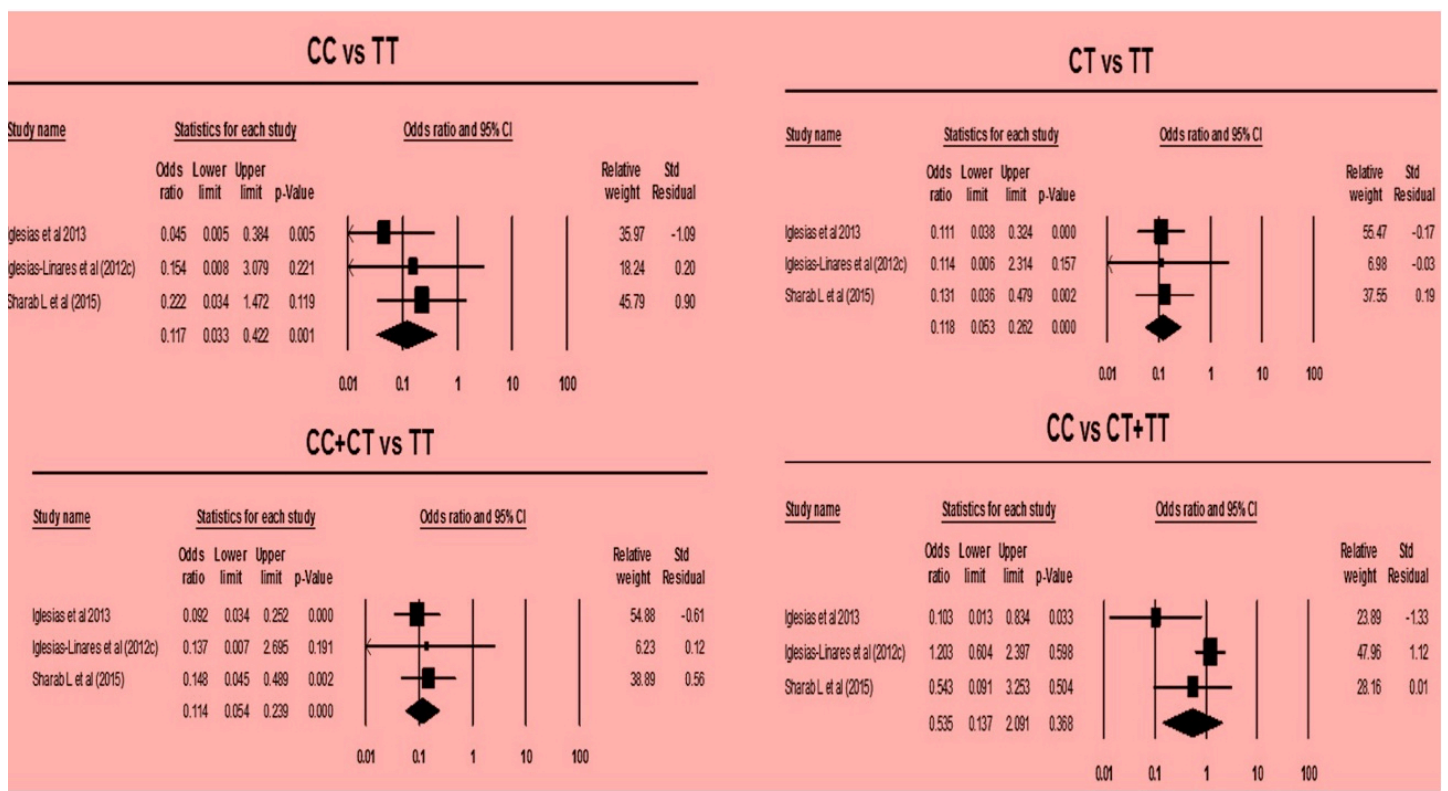

Figure 4. Forest plots of EARR risk associated with the interleukin-1RN (+2018) gene polymorphism.

The clinical and statistical heterogeneity were both observed among the studies in the dominant, codominant, and recessive models (Table 6). Sensitivity analysis was performed by omitting one publication at each step to examine the influence of each publication on the pooled OR. However, the heterogeneity stayed irrespective of which publication was omitted. No proof of publication bias was sighted while comparing the IL-1A (-889) and IL-1RN (+2018) gene polymorphisms with the overall risk of EARR included in the metaanalysis (Figure 5 and Table 7).

Table 6. Heterogeneity test among studies of IL-1A and IL-1RN gene.

\begin{tabular}{ccccc}
\hline Gene & Models & Q Statistics & p-value* & I2 Statistics (\%) \\
\hline IL-1A (-899) & CC vs. TT & 9.464 & 0.092 & 47.168 \\
& CT vs. TT & 6.241 & 0.283 & 19.884 \\
& CC+CT vs. TT & 8.067 & 0.153 & 38.021 \\
& CC vs. CT+TT & 8.487 & 0.131 & 41.086 \\
IL-1RN (+2018) & CC vs. TT & 1.229 & 0.541 & 0.001 \\
& CT vs. TT & 0.037 & 0.982 & 0.001 \\
& CC+CT vs. TT & 0.372 & 0.830 & 0.001 \\
& CC vs. CT+TT & 5.110 & 0.078 & 60.863 \\
\hline
\end{tabular}

*p-value for $\mathrm{Q}$ statistics.

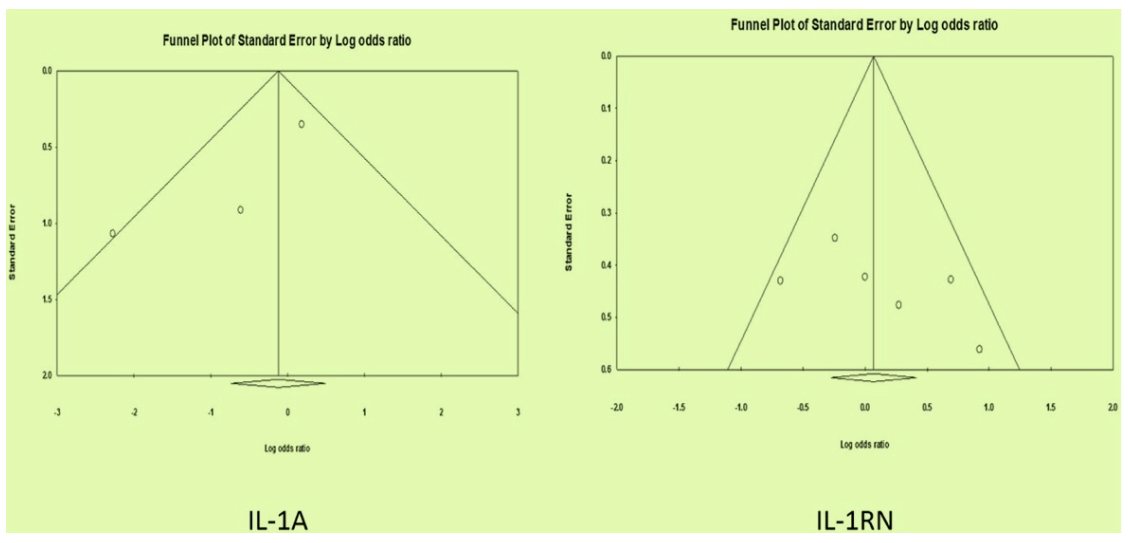

Figure 5. Funnel plot for the publication bias test for IL-1A (-889) and IL-1RN (+2018) gene polymorphism. 
Table 7. Publication bias among studies of IL-1A and IL-1RN gene.

\begin{tabular}{cccc}
\hline Gene & Genotypes & Begg's Test & Egger's Test \\
\hline IL-1A (-889) & CC vs. TT & 0.707 & 0.826 \\
& CT vs. TT & 1.000 & 0.722 \\
CC + CT vs. TT & 0.707 & 0.782 \\
IL-1RN (+2018) & CC vs. CT + TT & 0.259 & 0.209 \\
& CC vs. TT & 1.000 & 0.937 \\
& CT vs. TT & 1.000 & 0.942 \\
& CC + CT vs. TT & 1.000 & 0.745 \\
& CC vs. CT + TT & 0.296 & 0.264 \\
\hline
\end{tabular}

\section{Discussion}

In this latest systematic review, a total of nine published articles were selected for both IL-1A and IL$1 \mathrm{RN}$ genes, where five of them were classified as high-quality studies and the four remaining studies were determined as low-quality studies according to STREGA guidelines. This STREGA guideline is used to indicate the quality of genetic association studies regardless of the outcome of the studies based on a scoring system [20]. None of the selected publications for this current systematic review has attained the highest score set by the STREGA guideline, which is 20 ; however, five publications have scored $>10$, which might indicate the bias outcome of the genetic associations in relation to EARR. In addition, most of the orthodontic treatment studies and their genetic association seldom fulfill the STREGA or other genetic guidelines partly due to the methodological inaccuracies of the studies.

A total of seven published articles on IL-1A gene were included in this systematic review and all the articles were focused on IL-1A (-889) gene polymorphism. However, six out of seven studies were included in meta-analysis as one article [1] did not displayed the OR, which was the inclusion criteria of this review. On the other hand, a total of six previous studies of IL-1RN gene were included in this systematic review. Among these six studies, four studies were conducted on IL-1RN (+2018) gene polymorphism [2,8,18,19], one study on the IL-1RN (VNTR) gene polymorphism [3], one study on IL-1RN (+19835) gene polymorphism [20]. Therefore, the current study included the IL-1RN (+2018) gene polymorphism for the meta-analysis. However, among the four studies of IL-1RN (+2018) gene polymorphism, one study [19] did not displayed the OR, which was then not included in the current meta-analysis.

Cytokines, specifically IL, disturb bone remodeling and play a vigorous role in pathological and physiological bone regulation. Osteoclasts and osteoblasts like cells are involved in bone resorption and formation [21,22]. IL-1 is one of the most important monocyte-macrophage-derived cytokines that acts as a potent stimulator of bone resorption in organ culture [22]. IL-1 has been verified to stimulate bone resorption both in vitro and in vivo.

All of the studies considered in this systematic review have shown a negative association with IL-1A (889) gene polymorphism and EARR, except for one study conducted in the German population [7] revealed a positive association with EARR. In this case, the pooled outcomes of IL-1A (-889) gene polymorphism is in agreement with most of the outcomes of the previous investigations, which concluded that IL-1A (-889) gene polymorphism might not associate with the risk of EARR in orthodontic treatment. On the other hand, from the three studies with IL-1RN (+2018) gene polymorphism, two of the studies showed a positive association with EARR in orthodontic treatment. The pooled outcomes of IL-1RN (+2018) gene polymorphism in this current meta-analysis showed both dominant and co-dominant models indicating that there are associated with the risk of EARR. The probable link for the IL-1RN genetic predisposition would be through the increases of interleukin-1 receptor antagonist (IL-1Ra) protein that has been shown to be associated with a decreased rate 
of bone remodeling [23]. Imbalances in the cytokine level on the IL-1Ra stimulates bone modeling/remodeling and subsequent increase in radicular stress during orthodontic treatment that eventually develops the EARR [1]. However, the lack of publications on IL-1RN (+2018) gene polymorphism is a major obstacle to draw any conclusive result of the role of this particular gene and EARR during orthodontic treatment.

Statistical heterogeneity test performed using I2 and $Q$ statistics of the IL-1A (-889) gene polymorphism in this current meta-analysis showed no heterogeneity, which indicated that no bias in the design of analyzed studies [24]. Meanwhile, IL-1RN (+2018) gene polymorphism revealed mixed statistical results for different models, which suggests some bias of the analyzed studies [24]. However, clinical heterogeneity is always present in the meta-analysis due to different study design, intervention, sample size and outcomes. This current meta-analysis also indicated clinical heterogeneity based on the different ethnic background, methods of genotyping, sample size and outcomes.

EARR is a common complication that emerges during or after the orthodontic treatment and despite being a focus of many studies, many questions remain unanswered with regard to its risk factors. Therefore, evaluating the risk factor that influent the EARR development is a pivotal step for a successful orthodontic treatment. The outcome of the current systematic review and meta-analysis will undoubtedly aid further investigation to identify the main etiologic risk factor that are responsible for developing EARR.

\section{Conclusion}

The outcome of this meta-analysis suggested that IL-1A (-889) gene polymorphism was not associated with the development of EARR during orthodontic treatment. However, it was suggested that IL-1RN $(+2018)$ gene polymorphism might play a role in the development of EARR although there was statistical heterogeneity observed among the published results. Nevertheless, the heterogeneity among the published studies is not fully understood. Further studies are needed to verify the possible association of IL-1A and IL$1 \mathrm{RN}$ genes in the occurrence of EARR in some individuals undergoing orthodontic treatment.

\section{Authors' Contributions}

\begin{tabular}{|c|c|c|}
\hline SAN & https://orcid.org/0000-0001-7730-4481 & $\begin{array}{l}\text { Conceptualization, Methodology, Formal Analysis, Investigation, Data Curation, Writing - } \\
\text { Original Draft and Writing - Review and Editing. }\end{array}$ \\
\hline SJ & https://orcid.org/0000-0002-1470-8806 & $\begin{array}{l}\text { Conceptualization, Methodology, Investigation, Data Curation, Writing - Original Draft and } \\
\text { Writing - Review and Editing. }\end{array}$ \\
\hline NAR & https://orcid.org/0000-0002-9299-8554 & Conceptualization, Investigation, Writing - Original Draft and Writing - Review and Editing. \\
\hline FS & https://orcid.org/0000-0002-2097-1926 & $\begin{array}{l}\text { Conceptualization, Formal Analysis, Investigation, Resources, Data Curation, Writing - Original } \\
\text { Draft and Writing - Review and Editing. }\end{array}$ \\
\hline RB & https://orcid.org/0000-0002-7025-04.14 & Conceptualization, Methodology, Writing - Original Draft and Writing - Review and Editing. \\
\hline MKA & https://orcid.org/0000-0001-7131-1752 & Conceptualization, Writing - Original Draft, Writing - Review and Editing and Supervision. \\
\hline
\end{tabular}

\section{Financial Support}

None.

\section{Conflict of Interest}

The authors declare no conflicts of interest.

\section{Data Availability}

The data used to support the findings of this study can be made available upon request to the corresponding author.

\section{References}


[1] Al-Qawasmi RA, Hartsfield JK Jr., Everett ET, Flury L, Liu L, Foroud TM, et al. Genetic predisposition to external apical root resorption. Am J Orthod Dentofacial Orthop 2003; 123(3):242-52. https://doi.org/10.1067/mod.2003.42

[2] Iglesias-Linares A, Yanez-Vico R, Ballesta-Mudarra S, Ortiz-Ariza E, Ortega-Rivera H, Mendoza-Mendoza A, et al. Postorthodontic external root resorption is associated with IL1 receptor antagonist gene variations. Oral Dis 2012; 18(2):198-205. https://doi.org/10.1111/j.1601-0825.2011.01865.x

[3] Linhartova P, Cernochova P, Holla LI. IL1 gene polymorphisms in relation to external apical root resorption concurrent with orthodontia. Oral Dis 2013; 19(3):262-70. https://doi.org/10.1111/j.1601-0825.2012.01973.x

[4] Tomoyasu Y, Yamaguchi T, Tajima A, Inoue I, Maki K. External apical root resorption and the interleukin-1B gene polymorphism in the Japanese population. Orthodontic Waves 2009; 68(4):152-7. https://doi.org/10.1016/j.odw.2009.05.002

[5] Vijayalakshmi R, Geetha A, Ramakrishnan T, Emmadi P. Genetic polymorphisms in periodontal diseases: an overview. Indian J Dent Res 2010; 2 1(4):568-74. https://doi.org/10.4103/0970-9290.74226

[6] Dunn E, Sims JE, Nicklin MJ, O'Neill LA. Annotating genes with potential roles in the immune system: six new members of the IL-1 family. Trends Immunol 2001; 22(10):533-6. https://doi.org/10.1016/s1471-4906(01)02034-8

[7] Gülden N, Eggermann T, Zerres K, Beer M, Meinelt A, Diedrich P. Interleukin-1 polymorphisms in relation to external apical root resorption (EARR). J Orofac Orthop 2009; 70(1):20-38.

https://doi.org/10.1007/s00056-009-8808-6

[8] Iglesias-Linares A, Yanez-Vico RM, Ballesta-Mudarra S, Ortiz-Ariza E, Mendoza-Mendoza A, Perea-Perez E, et al. Interleukin 1 receptor antagonist (IL1RN) genetic variations condition post-orthodontic external root resorption in endodontically-treated teeth. Histol Histopathol 2013; 28(6):767-73. https://doi.org/10.14670/HH-28.767

[9] Borilova Linhartova P, Cernochova P, Kastovsky J, Vrankova Z, Sirotkova M, Izakovicova Holla L. Genetic determinants and postorthodontic external apical root resorption in Czech children. Oral Dis 2017; 23(1):29-35. https://doi.org/10.1111/odi.12564

[10] Pereira S, Lavado N, Nogueira L, Lopez M, Abreu J, Silva H. Polymorphisms of genes encoding P2X7R, IL-1B, OPG and RANK in orthodontic-induced apical root resorption. Oral Dis 2014; 20(7):659-67. https://doi.org/10.1111/odi.12185

[11] Nowrin SA, Jaafar S, Ab Rahman N, Basri R, Alam MK, Shahid F. Association between genetic polymorphisms and external apical root resorption: A systematic review and meta-analysis. Korean J Orthod 2018; 48(6):395-404. https://doi.org/10.4041/kjod.2018.48.6.395

[12] Wu FL, Wang LY, Huang YQ, Guo WB, Liu CD, Li SG. Interleukin-1 $\beta+3954$ polymorphisms and risk of external apical root resorption in orthodontic treatment: A meta-analysis. Genet Mol Res 2013; 12(4):4678-86. https://doi.org/10.4238/2013.October.18.6

[13] Landis JR, Koch GG. The measurement of observer agreement for categorical data. Biometrics 1977; 33(1):159-74.

[14] Begg CB, Mazumdar M. Operating characteristics of a rank correlation test for publication bias. Biometrics 199; $50(4): 1088-101$.

[15] Egger M, Smith GD, Schneider M, Minder C. Bias in meta-analysis detected by a simple, graphical test. BMJ 1997; 315(7109):629-34. https://doi.org/10.1136/bmj.315.7109.629

[16] Iglesias-Linares A, Yañez-Vico R, Ballesta S, Ortiz-Ariza E, Mendoza-Mendoza A, Perea E, et al. Interleukin 1 gene cluster SNPs (rs1800587, rs1143634) influences post-orthodontic root resorption in endodontic and their contralateral vital control teeth differently. Int Endod J 2012; 45(11):1018-26.

[17] Iglesias-Linares A, Yañez-Vico R-M, Ortiz-Ariza E, Ballesta S, Mendoza-Mendoza A, Perea E, et al. Postorthodontic external root resorption in root-filled teeth is influenced by interleukin-1 $\beta$ polymorphism. J Endod 2012; 38(3):28387.

[18] Sharab L, Morford L, Dempsey J, Falcão-Alencar G, Mason A, Jacobson E, et al. Genetic and treatment-related risk factors associated with external apical root resorption (EARR) concurrent with orthodontia. Orthod Craniofac Res 2015; 18(suppl 1):71-82. https://doi.org/10.1111/ocr.12078

[19] Guo Y, He S, Gu T, Liu Y, Chen S. Genetic and clinical risk factors of root resorption associated with orthodontic treatment. Am J Orthod Dentofacial Orthop 2016; 150(2):283-89. https://doi.org/10.1016/j.ajodo.2015.12.028.

[20] Aminoshariae A, Aminoshariae A, Valiathan M, Kulild JC. Association of genetic polymorphism and external apical root resorption. Angle Orthod 2016; 86(6):1042-9. https://doi.org/10.2319/011916-50.1

[21] Pereira S, Nogueira L, Canova F, Lopez M, Silva H. IRAK 1 variant is protective for orthodontic-induced external apical root resorption. Oral dis 2016; 22(7), 658-64. https://doi.org/10.1111/odi.12514

[22] Roodman GD. Role of cytokines in the regulation of bone resorption. Calcif Tissue Int 1993; 53(suppl 1):S94-98. https://doi.org/10.1007/BFO1673412

[23] Gowen M, Wood DD, Ihrie EJ, McGuire MK, Russell RGG. An interleukin 1 like factor stimulates bone resorption in vitro. Nature 1983; 306(5941):378-80. https://doi.org/10.1038/306378a0

[24] Salla JT, de Albuquerque Taddei SR, Queiroz-Junior CM, Junior IA, Teixeira MM, Silva TA. The effect of IL-1 receptor antagonist on orthodontic tooth movement in mice. Arch Oral Biol 2012; 57(5):519-24. https://doi.org/10.1016/j.archoralbio.2011.09.018 